\title{
Community Participation in the Implementation of School Programs
}

\author{
Feni Tutut Wahyuningsih \\ Department of Educational Administration \\ State University of Malang, Indonesia \\ fenitututw03@gmail.com
}

\author{
Raden Bambang Sumarsono \\ Department of Educational Administration \\ State University of Malang, Indonesia \\ raden.bambang.fip@um.ac.id
}

\begin{abstract}
The purpose of this study is to find out: (1) the form of community participation activities in the implementation of school programs; and (2) the school strategy in improving the participation of the community. This research uses quantitative approach with descriptive research design case study type. Data collection using in-depth interview technique, observation, and documentation study. Data analysis technique in this research using flow model analysis technique which includes three step process of data analysis that is, data reduction, data presentation, and data verification. The results of the study show that: (1) the form of community participation, including: "paguyuban" in each class, giving suggestions to school programs, involving religious figures on religious celebrations, monitoring of children's learning at home, promoting schools, school; and (2) school strategies to increase community participation, by involving the community in school activities, utilizing social media in informing school activities, making house visits and holding meetings with parents, and holding exhibitions of works and achievements learners.
\end{abstract}

Keywords: community participation, school program

\section{INTRODUCTION}

Education is a shared responsibility between government, parents and the community, better known as the Education Center. Therefore, the participation of parents and the community is necessary for the smooth implementation of school programs. In many cases, the type of community participation can take the form of individual, group, family, professional organization, and so on. This is as mandated in Law Number 20 Year 2003 regarding National Education System Article 54, which states that community participation in education includes the participation of individuals, groups, families, professional organizations, employers and community organizations in the implementation and quality control of services education. It suggests a strong attachment between government (school), parent, and community. Kusmintardjo (2010) states that when there is a strong link between school, family, and community, and involves actively helping the learning and development efforts of learners, this will have a positive impact on education. Meanwhile Sumarsono et. al. (2016) revealed that the joint responsibility between parents, community, and schools in improving the quality of education should not be ignored.

The process of organizing education in schools will be able to succeed optimally, if supported by all parties, whether resources come from schools, parents, and society at large (Wiyono, 2010; Benty and Gunawan, 2015). Community participation is indispensable, both in material and non-material, to the attainment of successful education in schools. That's what underlies the need for schools to establish relationships with the community. The relationship between school and community is a form of shared responsibility between school and community towards the implementation of education.

Various research results reveal the importance of community participation in organizing school programs to improve the quality of education. The findings of research by Preedy (1993) showed that the involvement of parents in school activities have a positive effect on the progress and development of student learning. Studies conducted by other researchers also suggest that parental involvement is an aspect that affects school effectiveness. Meanwhile, the Hewison \& Tizard (1980) study results indicate a relationship between parental involvement and the achievement of reading high school students. Murillo (2002) reports on effective school improvement research in Spain that community participation is vital to improving the quality of a school. Kimaro and Machumu (2015) through the results of his research stated that the finding suggest that there is an existance of a positive and significant relationship between parental involvement in the school activities of their children and academic achievement. Meanwhile, Castro e.t al. (2015) through the results of the study revealed that, parental involvement will lead to the achievement of academic achievement of children in school.

Optimizing the participation of the community in the implementation of school programs can be through various ways or strategies. Sumarsono (2017) states that the strategies undertaken by schools in developing partnerships with parents include: (1) strengthening two-way communication; (2) strengthening parent associations through class associations; (3) providing excellent school programs; and (4) the creation of a positive school climate. This is in line with Bacharach (1990) opinion that community participation can take place effectively, when schools can communicate with communities clearly and intensively. Communication is one of the most crucial means to build good cooperation or partnership with the community. Therefore, schools should allow sufficient time to communicate regularly with parents (Kusmintardjo, 2010; Benty and Gunawan, 2015).

Based on the results of the study, it is clear that the participation of the community towards the implementation of school activities program is expected to be realized properly. Therefore, on this occasion, the researcher will attempt to reveal about: (1) the form of community participation in school; and 
(2) the school strategy in improving the community participation.

\section{METHODS}

This research uses qualitative approach with descriptive research design of case study. Based on the research design conducted, the presence of researchers is necessary because researchers play a key instrument in digging information in depth and detail. The research was conducted at public elementary school (SDN) Rampal Celaket 1, which is located at Tretes Selatan Street 26 Lowokwaru, Malang. Sources of data in this study using primary and secondary data. Primary data were obtained through a series of interviews with principals, classroom teachers, parents, school committee managers, and parent associations. Meanwhile, secondary data obtained through documentation and observation studies which then analyzed and used as supporting evidence.

The data collection procedure in this study used three techniques: indepth interview, observation, and documentation study. Meanwhile, to analyze the data using three stages of data collection, data display, data condensation and conclusion (Miles and Huberman, 1994; Gunawan, 2016). These stages are used to select and filter information according to the research focus so that it can be concluded in accordance with the information obtained. The analysis of individual case data conducted in this study includes data analysis during collection and after completion of data collection in the field.

Analysis of data during the field, following the principles suggested by Bogdan and Biklen (2003) are: (1) seeking to immediately narrow the focus of the study; (2) determine the form of study; (3) develop analytical questions; (4) planning the next collection of data by taking into account the previous findings; (5) to write as many observer comments as to the developing ideas; (6) write memos about something being studied; (7) expressing ideas and themes about the subject; (8) reviewing relevant books; and (9) connecting findings with metaphors, analogies, and concepts. Meanwhile, post-field data collection analysis was considered between Bogdan and Biklen (2003) suggestions: (1) developing coding categories; (2) create a setting or link (context); (3) create a situation code; (4) understanding perspective by subject; (5) understanding the subject's way of thinking about people or objects; (6) generate process code; (7) generate activity code; (8) generate event code; (9) create a code of strategy; (10) create a social or structured relation code; (11) create method code; and (12) pay attention to predetermined code.

Steps to get the right conclusions in qualitative research is by checking the validity of data. Data that has been collected by researchers examined its validity, so it can be accounted for and can serve as a strong basis in drawing conclusions scientifically. Checking the validity of the data in this study, the researchers adopted Berg's (2004), and Johnson \& Cristensen (2004), which examined the validity of the data in this study by using techniques of credibility, transferability and confirmability.

\section{RESULT AND DISCUSSION}

There are two focuses of this study as has been confirmed above. Based on the results of collected data analysis, three themes can be identified as findings, namely: (1) form of community participation; and (2) school strategies to increase community participation. The form of community participation in SDN Rampal Celaket 1 is physical and non-physical. Physical form of community participation includes energy and material, while the non-physical form that is tangible delivery of ideas or ideas. The vehicle for the distribution of community participation in SDN Rampal Celaket 1 was formed parent group of learners of each class. Submission of ideas or ideas as a form of parental participation to the implementation of school programs, through the paguyuban class.

Physical form of community participation is not in the form of money but needs required by each class, such as the provision of medicine boxes, brooms, maintenance of the school's beauty, painting the classroom, the procurement of books for the corner reading and others. In the lead up to the reception of new learners, parents engage in school promotion activities to kindergarten. Parents also participate in monitoring the development of children's learning through a liaison book. Parents can monitor and learn the progress of learners learn in school and vice versa. In the liaison book the parents can also write their needs to the teacher, for example want to meet with the teacher.

Various school activities involving community participation in SDN Rampal Celaket 1, among others: (1) outbound activities, ranging from place search, consumption, activity preparation is fully handled by the parents of learners with the direction of the teacher; (2) major religious activities, such as Isro Mi'roj, maulid nabi, and pondok ramadhan, in the event must involve religious leaders as preachers; (3) Green School Festival competition, the school involves all school stakeholders; and (4) other programs involving community participation.

The findings are certainly in line with Ornstein \& Levine (1985) opinion that parents can be involved in planning and solving problems in the field of curriculum or learning programs, as well as policy on student affairs. Similarly, Bacharach (1990) states, their involvement (parents) can help prepare everything their sons and daughters need as long as, even after school lessons. Another explanation was put forward by Bacharach (1990) that, parents can help prepare everything their sons and daughters need as they attend art performances and exhibitions.

Furthermore, Moles (1992) explains that community participation in education can vary in form and level, both in and out of school. Such involvement or participation includes various activities prepared and assisted by the school, and strengthens community participation (parent) in the learning and development of their child. Or it could also help classroom teachers explain specific topics according to their skills or skills and help school visits to specific objects in society (Reynolds, et. al, 1996). Meanwhile, the research 
results Sumarsono, et al. (2016) reveals that parents' participation in improving school quality in the student aspect is seen in the interest and talent development activities of students packaged in extracurricular programs, celebrations or anniversaries of national and religious holidays, graduation of Grade 6 graduates, Pondok Ramadhan, Gema Dzulhijah, and accompanying children in the race.

The community has great potential in assisting schools in developing and implementing program activities, but it all depends on how schools approach or empower people's potential, especially parents. The findings of the study indicate that the strategies that schools undertake to improve community participation are to establish effective communication with parents and learners of the community and involve them in the implementation of school programs. Not all parents of students and the community who participated actively in the program or activities in the school. The way schools overcome this is to make home visits and meet with parents of learners. The school tries to give understanding that community participation is needed by the school, because without the help from the school community will not be able to run the school program optimally. Home visits are also used to convey the development of learners as well as problems at school.

In addition to home visit and meeting techniques, schools also use electronic techniques to further increase the interest of the community to actively participate in the school program. Schools have a variety of social media accounts in which there are postings of school activities and achievements that have been successfully achieved school. In establishing communication with parents, school students also use whatsapp and fuel. So when there are parents learners and people who want to express opinions can be directly through whatsapp or BBM.

Another strategy that schools do is to use the demonstration technique, namely by holding an exhibition of the work of learners as well as achievements achieved learners. School invites parents and community to see the exhibition. It is hoped that the community will be awakened by the awareness that community participation in supporting the school program is very important to achieve the success of the school program.

The results are in line with Sumarsono (2017) finding that the strategies undertaken by schools in developing partnerships with parents include: (1) strengthening two-way communication; (2) strengthening parent associations through class associations; (3) providing leading school programs; and (4) creation of a positive school climate. This is in line with Bacharach (1990) opinion that community participation can take place effectively, when schools can communicate with communities clearly and intensively. Communication is one of the most crucial means to build good cooperation or partnership with the community. Therefore, schools should allow sufficient time to communicate regularly with parents (Kusmintardjo, 2010). There are several things that need to be done by the school in improving the intensity of communication ties with parents, such as through the media: letters, websites, school magazines, school bulletins, telephone / mobile phones, and other social media such as whatshap, blackberry massanger, and line. Other things that can be done by the school in empowering parent transports through effective communication (Rohiat, 2010; Benty and Gunawan, 2015).

The results of Radu (2011) study of parents involvement in schools in 10 Eastern European countries show that the skills and communication strategies that teachers apply to parents will have an impact on the active involvement of parents in some school activities. The existence of interaction or communication between parents and the school becomes the key to effective child education process, both at school and at home. This demonstrates the importance of communication between schools and parents for the sustainability of school partnerships and parents.

\section{CONCLUSION}

Based on the result of the research, it can be concluded that: (1) the form of community participation in school program implementation is realized in physical and non-physical form. In physical form, community participation, in the form of provision of medicine boxes, floor cleaning brooms, maintenance of school beauty, classroom painting, and the procurement of books for the reading corner; and (2) the participation of the community in a nonphysical form, manifested in terms of the delivery of ideas or ideas to the implementation of school activities program.

Various school activities involving community participation in SDN Rampal Celaket 1, among others: (1) outbound activities, ranging from place search, consumption, activity preparation is fully handled by the parents of learners with the direction of the teacher; (2) major religious activities, such as Isro Mi'roj, Maulid Nabi, and Pondok Ramadhan, in the event must involve religious leaders as preachers; (3) Green School Festival competition, the school involves all school stakeholders; and (4) other programs involving community participation.

School's strategy to increase community participation is to establish effective communication with parents of learners and community by using social and communication tools like whatsapp (WA) or blackberry (BBM) and involving them in school program implementation. The next strategy is home visits and meetings with parents of learners. Home visits are used to convey the development of learners and problems that exist in schools. Another strategy that schools do by using demonstration techniques, namely by holding exhibits about the work of learners and achievements achieved learners.

\section{REFERENCES}

[1] Bacharach. S. B. 1990. Education Reform: Making Sense of It All. Boston: Allyn and Bacon. 
[2] Benty, D. D. N., and Gunawan, I. 2015. Manajemen Hubungan Sekolah dan Masyarakat. Malang: State University of Malang.

[3] Berg, B. L. 2004. Qualitative Research Methods: For the Sosial Sciences. Boston: Pearson.

[4] Bogdan, R. C. \& Biklen, S. K. 2003. Qualitatif Research for Education (An Introduction to Theories and Methods). Boston: Allyn \& Bacon, Inc.

[5] Castro, M., Casas, E., Martin, E., Lizasoain, L., Asencio, E., \& Gaviria, J. 2015. Parental Involvement on Student Academic Achievemnt: A Meta-Analysis. Education Research Review, 14, 33-46.

[6] Gunawan, I. 2016. Metode Penelitian Kuantitatif. Retrieved June 7, 2017, from http://fip.um.ac.id/wpcontent/uploads/2015/12/2_Metpen-Kuantitatif.pdf.

[7] Hewison, J., \& Tizzard, J. 1980. Parental Involvement and Reading Attainment. Britis Journal of Educational Psychology, 50(3), 209-215.

[8] Johnson, B., \& Cristensen, L. 2004. Educational Research: Qualitative and Mixed Approaches. Boston: Pearson

[9] Kimaro, A. R. \& Machumu, H.J. 2015. Impacts of Parental Involvement in School Activities on Academic Achievement of Primary School Children. International Journal of Education and Research, 3(8).

[10] Kusmintardjo. 2010. Manajemen Keterlibatan Orang Tua dalam Pendidikan. Manajemen Pendidikan, 23(2), 195-203.

[11] Milles, M. B., \& Huberman, A. M. 1994. Qualitative Data Analysis: An Sexpended Sourcebook. Thousand Oaks CA: Sage Publications.

[12] Moles, O. 1992. Synthesis or Recent Research on Parent Participation on Children's Education. Educational Leadership, 44.

[13] Murillo, I. I. 2002.Good Effective School Improvement in Spain. Educational Research and Evaluation, 8(4), 387-410.

[14] Orrstein, A. C. \& Levine, D. U. 1985. An Introducting to the Foundations of Education. Boston: Houghton Mifflin Company.

[15] Preedy, M. 1993. Managing The Effective School. London: The Open University.

[16] Radu, B. M. 2011. Parental Involvement: in School: A Study of Resources, Mobilization, and in Herent Inequality. Journal of Comparative Research in Anthropology and Sociaology, 2(2), 103-115.

[17] Reynolds, D., Bollen, R., Creemers, B., Hopkins, D., Stoll, L., \& Lagerwejj, N. 1996. Making Good Schools: Linking Schools Effectiveness and School Improvement. London: Routledge.

[18] Rohiat. 2010. Manajemen Sekolah: Teori Dasar dan Praktik. Bandung: PT Rafika Aditama.

[19] Sumarsono, R. B. 2017. Partnership of Parents and Madrasah to Realize the Quality of Education. Proceedings $2^{\text {nd }}$ International Conference on Education Management and Administration. Atlantis Press.

[20] Sumarsono, R. B., Imron, A., Wiyono, B. B., \& Arifin, I. 2016. Parent's Participation in Improving the Quality of Elementary School in the Malang of City, East Java, Indonesia. International Education Studies, 9(10).

[21] Undang-undang Nomor 20 Tahun 2003 tentang Sistem Pendidikan Nasional. 2014. Jakarta: Sinar Grafika.

[22] Wiyono, B. B. 2010. Partisipasi Masyarakat terhadap Pelaksanaan Kegiatan Pendidikan. Manajemen Pendidikan, 23(1), 1-11. 